\title{
Preservation of GLUT 2 expression in islet beta cells of Kilham Rat Virus (KRV) - infected diabetes-resistant BB/Wor rats
}

\author{
M. Stubbs, D. L. Guberski, A. A. Like \\ University of Massachusetts Medical School, Worcester, Massachusetts, USA
}

Summary Loss of GLUT 2, the glucose transporter isoform of pancreatic beta cells, has been reported to accompany the onset and perhaps contribute to the pathogenesis, of insulin-dependent and non-insulindependent diabetes mellitus in $\mathrm{BB} /$ Wor and Zucker fatty rats. In this study we investigated the effect of Kilham Rat Virus infection on GLUT 2 expression in diabetes-resistant $\mathrm{BB} /$ Wor rats. Viral antibodyfree diabetes-resistant rats do not develop spontaneous diabetes, but inoculation with Kilham Rat Virus induces autoimmune beta-cell destruction and hyperglycaemia. Pancreas sections from normoglycaemic diabetes-resistant $\mathrm{BB} /$ Wor rats were obtained 5, 7 and 25 days after inoculation with Kilham Rat Virus and stained for GLUT 2 using a rabbit polyclonal antibody. At all time points, beta cells displayed GLUT 2 expression comparable to uninfected diabetes-resistant controls. Immunostained insulin content of the beta cells also remained unchanged. Sections were also examined from Kilham Rat Virus inoculated diabetes-resistant rats with lymphocytic insulitis or diabetes. GLUT 2 and insulin immunostaining were unchanged in non-diabetic rats with early insulitis. GLUT 2 beta-cell staining was variably reduced in diabetic rats with established insulitis and reduced beta-cell insulin immunostaining. Hence, the initial stages of Kilham Rat Virus-induced diabetes in diabetes-resistant rats are not accompanied by a significant reduction in GLUT 2 expression. These results suggest that the loss of GLUT 2 does not play a significant role in the aetiology of diabetes in the Kilham Rat Virus-infected diabetes-resistant $\mathrm{BB} /$ Wor rat. [Diabetologia (1994) 37: 1186-1194]

Key words GLUT 2, BB/Wor rats, Kilham Rat Virus, autoimmune diabetes mellitus, beta cell, islets of Langerhans, parvoviridae infections.
The GLUT 2 glucose transporter isoform is the predominant type found in pancreatic beta cells $[1,2]$. First characterized by Thorens et al. [1] this species has a high $\mathrm{K}_{\mathrm{m}}(17 \mathrm{mmol} / \mathrm{l})$ for glucose [3], therefore glucose uptake is not normally rate limiting in glucose-mediated insulin secretion. Several workers have reported the loss of GLUT 2 from beta cells in

Received: 11 March 1994

and in revised form: 10 June 1994

Corresponding author: Dr. M. Stubbs, Department of Pathology, University of Massachusetts Medical Center, 55 Lake Avenue North, Worcester, MA 01655, USA

Abbreviations: KRV, Kilham Rat Virus; NHS, normal horse serum; BB/Wor, Biobreeding/Worcester rats. animal models of insulin dependent diabetes mellitus (IDDM) and non-insulin dependent diabetes mellitus (NIDDM) [4-7]. The Zucker diabetic fatty (ZDF) rat displays obesity and insulin resistance. Only male rats develop diabetes with an associated loss of insulin response to glucose [4]. Obese male diabetic $Z D F$ rats revealed decreased beta-cell GLUT 2 protein and mRNA at the onset of diabetes, compared to obese non-diabetic female and lean non-diabetic male Zucker rats $[4,6]$. Glucose-induced insulin release in obese diabetic ZDF rats was correlated with the level of beta-cell GLUT 2; glucose-induced insulin release by the isolated perfused pancreas was absent in rats with fewer than $60 \%$ GLUT 2 positive beta cells. In contrast, arginine infusions elicited a strong insulin secretory response, 
even in diabetic animals with very low beta-cell GLUT 2 levels [4].

The BB/Wor rat develops spontaneous autoimmune insulitis, leading to beta-cell destruction in a manner resembling IDDM in humans. Orci et al. [8] reported that decreased numbers of GLUT 2 positive beta cells were present on the first day of overt diabetes. Furthermore, although there was no detectable insulin response to glucose in the isolated perfused pancreas of acutely diabetic BB rats, arginine infusions still elicited a brisk and significant insulin response [8]. Therefore, the loss of GLUT 2 from the remaining beta cells appeared to augment the loss of beta cell function due to autoimmune destruction.

Neither in vivo nor in vitro elevated glucose levels have been reported to reduce beta-cell surface GLUT 2 immunostaining in islets of non-diabetic lean rats [6]. Immunodetectable beta cell GLUT 2 was not reduced in lean Wistar rats with chronic hyperglycaemia ( 7 days) induced by i.v. infusions of a $50 \%$ glucose solution [6]. Conversely, the reduction of glycaemic levels in acarbose-fed obese male diabetic ZDF rats did not restore beta cell GLUT 2 levels to those of non-diabetic obese female rats or lean animals [6]. Therefore, the reduction in betacell GLUT 2 observed in the lean BB and obese ZDF animal models was interpreted to be a manifestation of an intrinsic defect in the beta cell rather than the consequence of hyperglycaemia.

The BBDR/Wor (diabetes-resistant) rat was derived from parental diabetes-prone (DP) progenitors at the University of Massachusetts, Worcester colony. Unlike DP rats, which show decreased numbers of circulating and tissue T lymphocytes (lymphopenia), DR rats are non-lymphopenic and do not develop insulitis or diabetes if raised in a viral antibodyfree (VAF) environment [9]. However, lymphocytic insulitis, beta cell destruction and diabetes are induced in DR animals infected with the parvovirus Kilham Rat Virus (KRV) [10]. DR rats housed in conventional (i.e. virus-containing) surroundings display a low incidence of spontaneous diabetes, which is greatly increased by treatments which perturb the immune system, e.g., polyinosinic-polycytidylic acid (poly I : C) injections [11, 12], depletion of RT6.1 + T-cells [13], X-irradiation [14] and cyclophosphamide [15].

The purpose of the present study was to evaluate the effects of KRV infection, and KRV-induced insulitis and diabetes on beta-cell GLUT 2 immunostaining in BBDR/Wor rats. We wanted to examine whether loss of GLUT 2 occurred in KRV-induced diabetes and whether it preceded or was concomitant with autoimmune beta-cell destruction. We thus wished to ascertain whether altered beta-cell GLUT 2 played a role in the KRV model of autoimmune diabetes.

\section{Materials and methods}

Animals. BBDR/Wor rats were produced in the NIH-supported research and contract colonies located at the University of Massachusetts Medical Center. DR rats have been inbred for more than 50 generations, and have been completely free of spontaneous insulitis and diabetes since the colony was Caesarian-derived into a Viral antibody-free facility in 1989. Rats were fed autoclaved chow (Purina 5010; Purina, St.Louis, Mo., USA) and given drinking water ad libitum.

To evaluate the effects of KRV infection on pancreatic islet morphology and immuno-histochemistry, we studied KRV-infected rats derived from two study groups. In study 1 , the "Time course study", pancreatic tissues were obtained from non-diabetic DR rats that were killed at early intervals after KRV infection, prior to the expected onset of hyperglycaemia. In study 2 , the "GLUT 2 expression during insulitis study", pancreata were analysed from animals with documented KRV-induced lymphocytic insulitis or diabetes.

Time course study. Twelve DR rats comprising both sexes, 2731 days of age, were injected i.p. with $0.1 \mathrm{ml}$ of a $1: 6$ dilution (approximately $5 \times 10^{7}$ plaque-forming units) of the University of Massachusetts KRV isolate [10]. Six of the 12 rats also received injections of anti-RT6.1 monoclonal antibody (DS4.23 from Dr. D. Greiner, University of Massachusetts Medical Center), $1.5 \mathrm{ml}$ i.p. daily for $1-4$ days before $\mathrm{KRV}$ injection. RT6 is an alloantigen found on $45 \%$ and $80 \%$ of peripheral CD4 and CD8 cells, respectively [16]. Two allelic forms exist, RT6.1 and RT6.2 [17]. The BBDR/Wor rat expresses the RT6.1 form [13]. Depletion of RT6.1 ${ }^{+} \mathrm{T}$ cells increases the frequency of diabetes in KRV-infected DR rats (Like, unpublished data). Animals were killed 5 days (3 rats, 1 DS4.23 treated), 7 days ( 4 rats, 3 DS4.23 treated) and 25 days (5 rats, 2 DS4.23 treated) after KRV injection.

GLUT 2 expression during insulitis study. Eighteen DR rats comprising both sexes, 18-57 days of age, were injected with $0.1-0.2 \mathrm{ml}$ of a $1: 6$ dilution (approximately $5 \times 10^{7}$ plaqueforming units) of either the University of Massachusetts KRV isolate or the National Cancer Institute KRV isolate (T953000, provided by W.Shek, Charles River Laboratory, Wilmington, Mass., USA), and killed at 34-85 days of age. One of the 18 rats also received injections of anti-RT6.1 monoclonal antibody, $2 \mathrm{ml}$ i. p. daily for $1-4$ days before KRV injection. Ten rats were diabetic when killed.

Diabetes testing. Animals were tested for glycosuria three times a week using TesTape. Tail blood was obtained from glycosuric animals for glucose measurements using a glucose analyzer (Beckman Glucose Analyzer 2, Irvine, Calif., USA). Diabetes was defined as $4+$ glycosuria and blood glucose greater than $13.9 \mathrm{mmol} / \mathrm{l}$.

Tissue processing and immunohistochemistry. Pancreatic tis sues were fixed in Bouin's solution and embedded in paraffin. For GLUT 2, we used an adaptation of the immunostaining method of Orci et al. [8]. Deparaffinized sections (4 um) were incubated with rabbit anti-GLUT 2 polyclonal antibody (\#1092 from C.B.Newgard and J.H.Johnson, University of Texas, Dallas, Tex., USA) at $1: 500$ dilution in buffer $(0.01 \mathrm{~mol} / 1$ sodium phosphate, $0.9 \%$ sodium chloride, $0.1 \%$ sodium azide, $0.1 \%$ bovine serum albumin (BSA) RIA grade, $\mathrm{pH} 7.4$ ) overnight at $4{ }^{\circ} \mathrm{C}$ in a saturated water vapour atmosphere. The sections were washed three times in $0.01 \mathrm{~mol} / \mathrm{l}$ sodium phosphate, $0.9 \%$ sodium chloride buffer, $\mathrm{pH} 7.4$, followed by a $1 \mathrm{~h}$ incubation at room temperature 

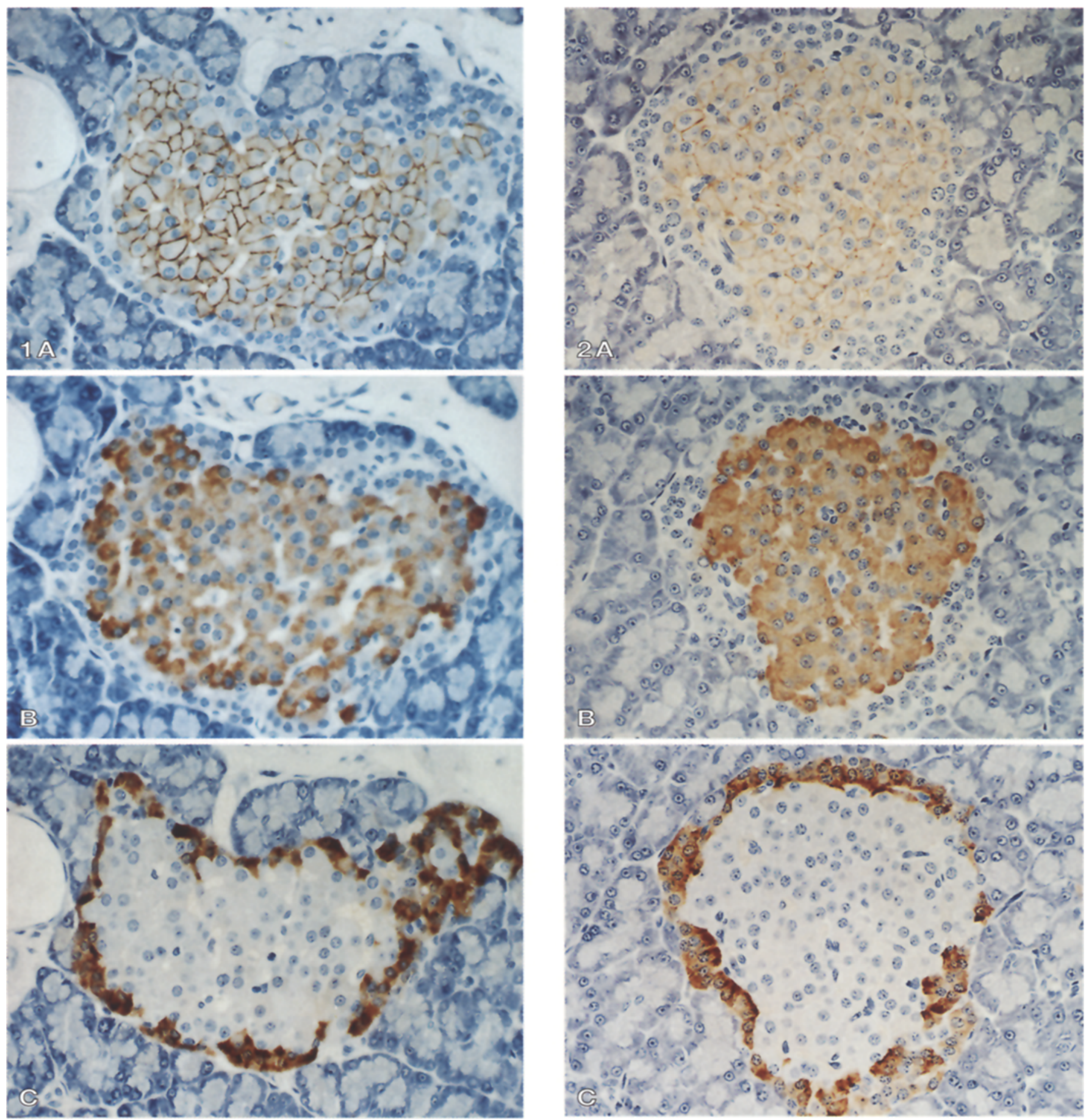

Fig. 1. (A-C). Consecutive or near-consecutive sections of pancreas immunoperoxidase stained for GLUT 2 (A), insulin (B) and glucagon (C), from an uninfected diabetes-resistant (DR) rat. GLUT 2 staining (brown reaction product) is localised on the membranes of the beta cells (defined by the area positive for insulin) and is absent from the glucagon positive alpha cells. Virtually all the betacells show detectable GLUT 2 and normal staining for insulin. Glucagon staining is also normal. Magnification $\times 100$

Fig. 2. (A-C). Consecutive or near-consecutive sections of pancreas immunoperoxidase stained for GLUT 2 (A), insulin (B) and glucagon (C), from normoglycaemic DR rats killed 5 days after KRV infection. GLUT 2 staining (brown reaction product) is localised on the membranes of the beta cells (defined by the area positive for insulin) and is absent from the glucagon positive alpha cells. Virtually all the beta cells show detectable GLUT 2 and normal staining for insulin. Glucagon staining is also normal. None of the KRV infected rats had received injections of anti-RT6.1 antibody. Magnification $\times 100$ 
with peroxidase conjugated porcine anti-rabbit antibody (Dakopatts, Glostrup, Denmark) $1: 100$ dilution in $0.01 \mathrm{~mol} / 1$ sodium phosphate, $0.9 \%$ sodium chloride, $\mathrm{pH} 7.4$. The sections were washed as before. Reaction product was revealed by a 90 -s incubation in $0.01 \mathrm{~mol} / 1$ sodium phosphate, $0.9 \%$ sodium chloride buffer $\mathrm{pH} 7.4$ containing $0.025 \% 3,3^{\prime}$-diaminobenzidine (Sigma, St. Louis, Mo., USA) $+0.015 \% \mathrm{H}_{2} \mathrm{O}_{2}$. For insulin and glucagon immunostaining, sections were incubated overnight at $4^{\circ} \mathrm{C}$ with either guinea-pig anti-porcine insulin (Dako, Carpinteria, Calif., USA), or rabbit anti-glucagon antibody (from Dr. M. Appel, University of Massachusetts Medical Center) at dilutions of $1: 150$ and $1: 2500$, respectively, in $0.05 \mathrm{~mol} / 1$ Tris, $0.9 \%$ sodium chloride, $1 \%$ normal horse serum (NHS), pH 7.6. Sections were washed for $10 \mathrm{~min}$ in the same buffer and incubated for $1 \mathrm{~h}$ at room temperature with swine anti-rabbit antibody (Dako, Glostrup, Denmark) $1: 200$ dilution in $0.05 \mathrm{~mol} / 1$ Tris, $0.9 \%$ sodium chloride, $1 \%$ NHS, pH 7.6. Sections were washed as before and incubated for $1 \mathrm{~h}$ with rabbit peroxidase anti-peroxidase conjugate (Dako, Glostrup, Denmark), 1 : 500 dilution in $0.05 \mathrm{~mol} /$ 1 Tris, $0.9 \%$ sodium chloride, $1 \%$ NHS, pH 7.6. Following a 10 -min wash in $0.05 \mathrm{~mol} / \mathrm{l}$ Tris, staining was revealed with a 4-7 min incubation in $0.02 \%$ diaminobenzidine in $0.05 \mathrm{~mol} / 1$ Tris, $0.9 \%$ sodium chloride, $0.01 \% \mathrm{H}_{2} \mathrm{O}_{2}$. All sections were counterstained with haematoxylin, dehydrated and mounted using Permount mounting medium (Fisher, Fair Lawn, N. J., USA).

Consecutive, or near-consecutive sections were immunostained for GLUT 2, insulin and glucagon. By examining all islets visible in the plane of the section, the degree of insulitis was estimated (none, mild, moderate, severe), as was the estimated percentage of remaining beta cells (visualised by insulin staining) staining visibly positive for GLUT 2. The amount of GLUT 2 expression was scored on an arbitrary scale of $1+$ to $4+$ as follows: $0-25 \%=1+; 25-50 \%=2+; 50-$ $75 \%=3+; 75-100 \%=4+$.

\section{Results}

Study 1. Of the twelve rats studied, none developed diabetes during the course of the experiment. After the animals were killed, subsequent immunohistochemical examination revealed mild insulitis in two of the rats (not treated with anti-RT6.1 monoclonal antibody) killed 25 days after KRV infection. All 12 rats showed GLUT 2 expression of $4+$.

Figures 1-4 show pancreatic sections from a normal uninfected DR rat (Fig. 1), and from selected examples of DR rats killed at 5 (Fig. 2), 7 (Fig. 3) and 25 (Fig. 4) days following KRV-infection, after staining for (a) GLUT 2, (b) insulin and (c) glucagon. GLUT 2 staining in normal rat islets (Fig. $1 \mathrm{a}$ ) is localized to the cell membranes of centrally located betacells (defined by positive staining for insulin, Fig. 1b), and is not present in the glucagon-positive peripheral alpha-cell area of the islet (Fig. 1c). At 5 (Fig. 2) and 7 (Fig.3) days after KRV injection, insulitis is not evident, beta cells appear normal, and GLUT 2, insulin and glucagon staining are unchanged. At 25 days post-infection (Fig. 4), mild lymphocytic peri-insulitis is present. The cytoarchitecture of the islets is, however, preserved and there is no diminution in beta- cell GLUT 2 staining (Fig.4a). Insulin (Fig.4b) and glucagon (Fig. 4c) staining are also unchanged. There was no difference in islet morphology or immunohistochemistry between unpretreated DR rats and DR rats pretreated with anti-RT6.1 monoclonal antibody (results not shown).

Study 2. Figures 5-8 illustrate consecutive or nearconsecutive sections of four different islets which depict mild (Fig.5) moderate (Fig.6) and severe (two stages, Figs. 7 and 8) lymphocytic insulitis. GLUT 2 staining is fully preserved in the surviving beta cells of the islet with mild insulitis (Fig. 5a). With moderate insulitis, there is focal reduction in GLUT 2 staining (Fig. 6a), particularly in beta cells adjacent to foci of lymphocyte infiltration. The reduction in GLUT 2 is more evident in Figure 7a. Total loss of GLUT 2 expression, however, is not noted until the number of surviving beta cells has been substantially reduced (Fig. 8 a). Note that the surviving GLUT 2 negative beta cells still reveal insulin immunostaining (Fig. 8 b). The intensity of glucagon staining is unchanged with the increasing degree of insulitis (Figs. 5c-8c), although the islet cytoarchitecture is disrupted.

Table 1 shows the combined results of Studies 1 and 2 and reveals the relationship between the degree of lymphocytic insulitis (none, mild, moderate, severe) and the estimated percentage of surviving beta cells expressing cell-surface GLUT 2 . None of the 14 rats without insulitis displayed any reduction in immunostainable beta-cell GLUT 2. In the six rats with mild insulitis, there was also no reduction in GLUT 2 immunostaining. Of the five rats with moderate insulitis, three revealed varying degrees of reduced GLUT 2 staining, and two revealed GLUT 2 on all or nearly all surviving beta cells. GLUT 2 staining was reduced in all five animals with severe insulitis. There were no apparent differences in the pattern of GLUT 2 expression in the rats treated with KRV alone and those which received anti-RT6.1 (DS4.23) antibody prior to KRV (data not shown).

Table 1. Correlation between the severity of insulitis and reduction in GLUT 2 expression in KRV-infected DR rats

\begin{tabular}{|c|c|c|c|c|}
\hline \multirow{2}{*}{$\begin{array}{l}\text { Level of GLUT } 2 \\
\text { expression }\end{array}$} & \multicolumn{4}{|c|}{ Insulitis } \\
\hline & None & Mild & Moderate & Severe \\
\hline $\begin{array}{l}4+ \\
3+ \\
2+ \\
1+\end{array}$ & $14(6)$ & $6^{1}$ & $\begin{array}{l}2(1)^{1} \\
1^{1} \\
2^{2}\end{array}$ & $\begin{array}{l}1^{1} \\
2^{2} \\
2^{2}\end{array}$ \\
\hline
\end{tabular}

Numbers refer to the number of animals wth the corresponding degree of insulitis and level of GLUT 2 expression $(1+\rightarrow 4+$ least $\rightarrow$ most $)$. Numbers in parentheses refer to the number of animals treated with anti-RT6.1 DS4.23 antibody. Superscript numbers represent the number of animals that were diabetic when killed 

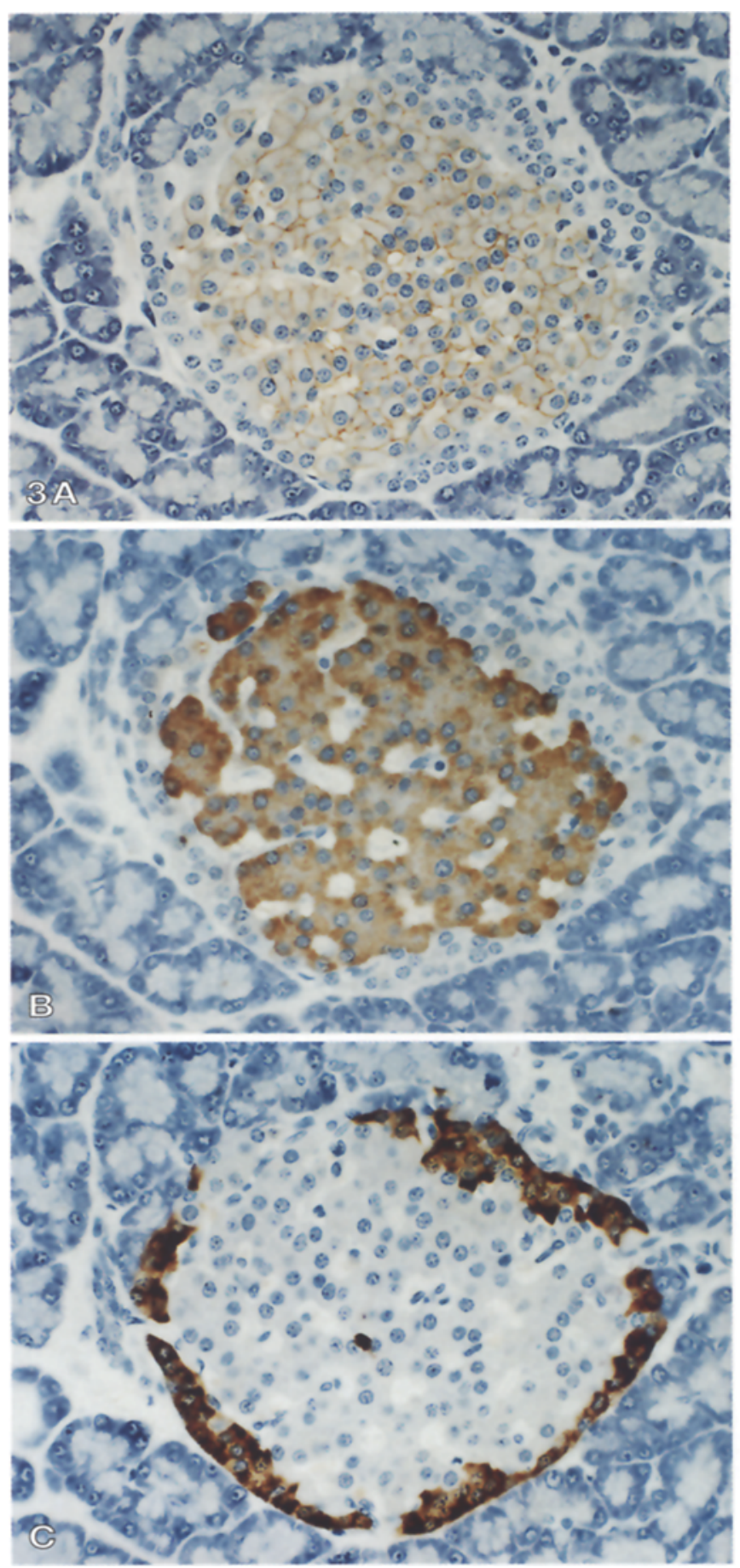

Fig. 3. (A-C). Consecutive or near-consecutive sections of pancreas immunostained for GLUT 2 (A), insulin (B) and glucagon (C), from normoglycaemic DR rats killed 7 days after KRV infection. GLUT 2 staining (brown reaction product) is localised on the membranes of the beta cells (defined by the area positive for insulin) and is absent from the glucagon positive alpha cells. Virtually all the beta cells show detectable GLUT 2 and normal staining for insulin. Glucagon staining is also normal. None of the KRV infected rats had received injections of anti-RT6.1 antibody. Magnification $\times 100$
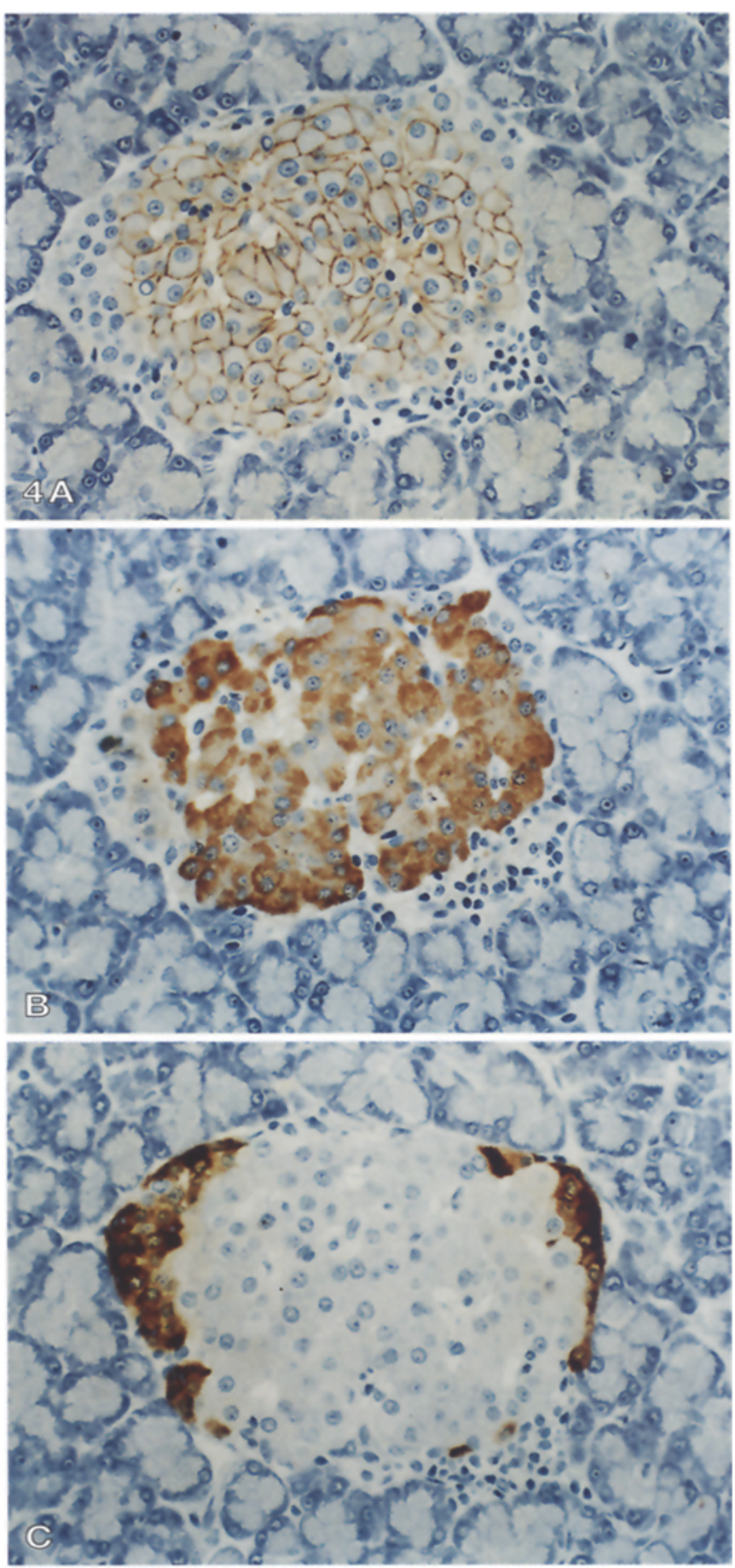

Fig. 4. (A-C). Consecutive or near-consecutive sections of pancreas immunostained for GLUT $2(\mathbf{A})$, insulin (B) and glucagon (C), from normoglycaemic DR rats killed 25 days after KRV infection. GLUT 2 staining (brown reaction product) is localised on the membranes of the beta cells (defined by the area positive for insulin) and is absent from the glucagon positive alpha cells. Virtually all the beta cells show detectable GLUT 2 and normal staining for insulin. Glucagon staining is also normal. Note the mild insulitis in the 25 day post-infection DR rat. None of the KRV infected rats had received injections of anti-RT6.1 antibody. Magnification $\times 100$ 

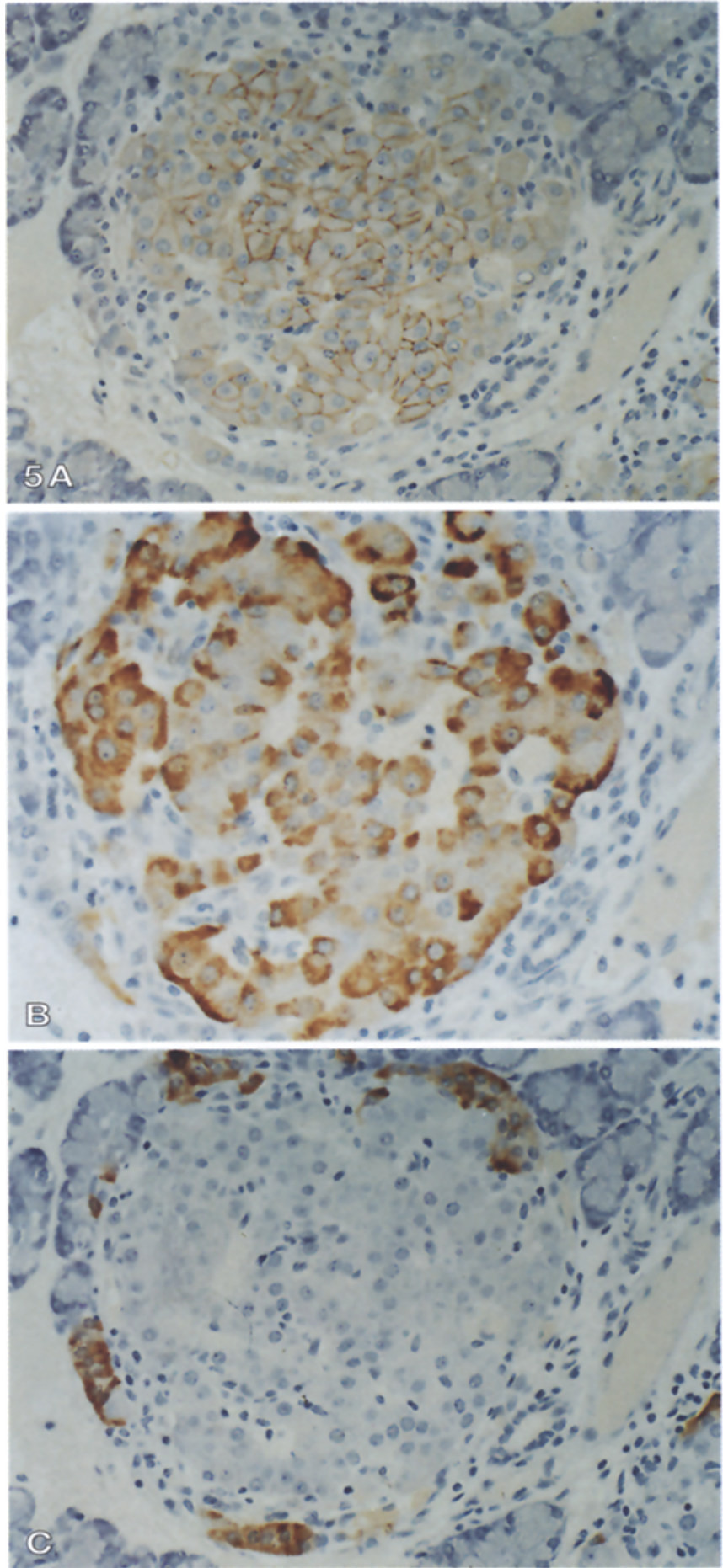

Fig.5. (A-C). Consecutive or near-consecutive sections of pancreas from KRV-infected diabetes resistant (DR) rats showing mild insulitis. GLUT 2 is present on nearly all betacells in the islet with mild insulitis. Immunoperoxidase stains for GLUT 2 (A), insulin (B) and glucagon (C). Magnification $\times 100$ (Fig. 5)

Of the ten diabetic animals, four displayed GLUT 2 levels equal to or greater than $3+$ on the remaining beta cells, suggesting that the hyperglycaemia per se is not responsible for the down-regulation of betacell surface GLUT 2.
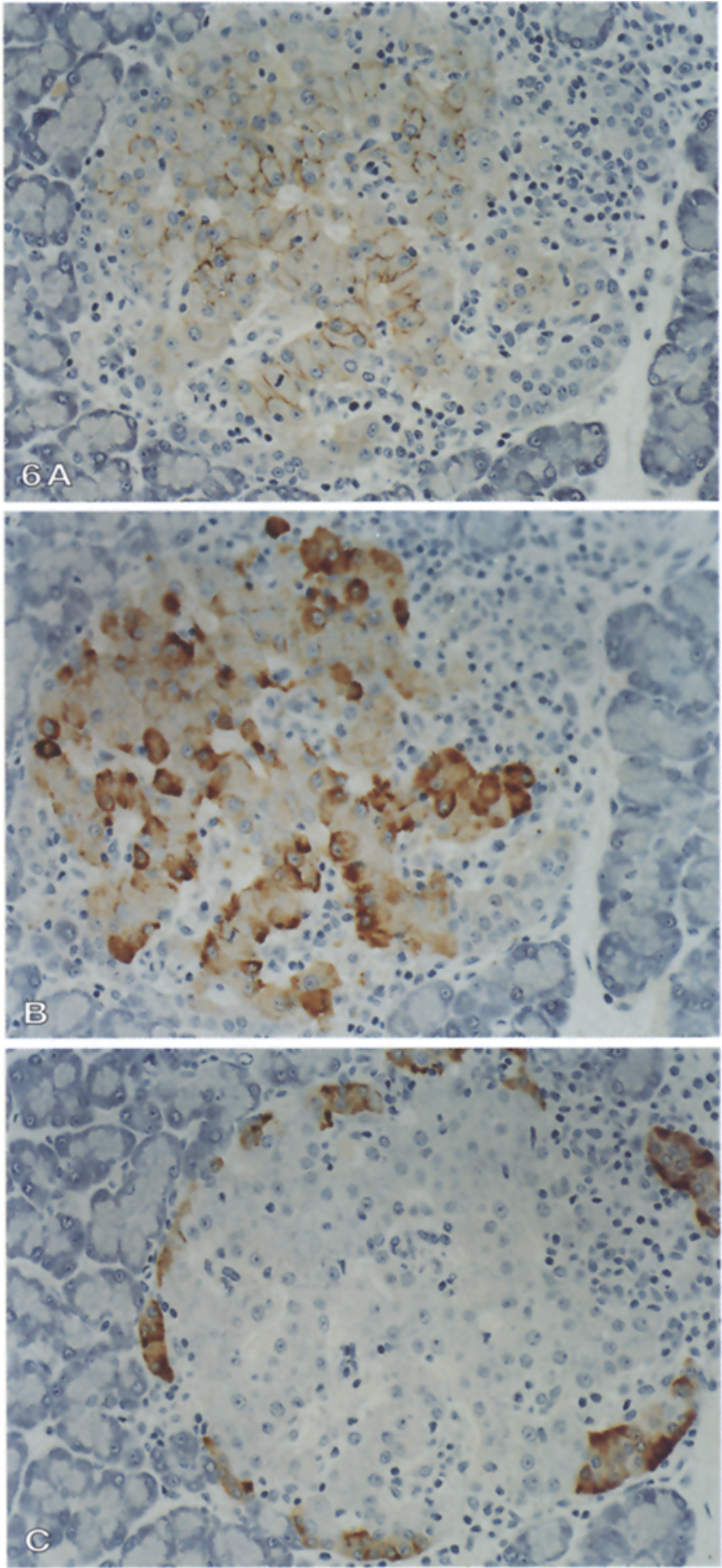

Fig. 6. (A-C). Consecutive or near-consecutive sections of pancreas from KRV-infected diabetes resistant (DR) rats showing moderate insulitis. There is focal reduction in GLUT 2 expression in beta cells adjacent to infiltrating lymphocytes. Immunoperoxidase stains for GLUT 2 (A), insulin (B) and glucagon (C). Magnification $\times 80$

\section{Discussion}

It has been previously reported that a reduction of beta-cell immunostainable GLUT 2 accompanies the onset of both IDDM and NIDDM in animal mod- 

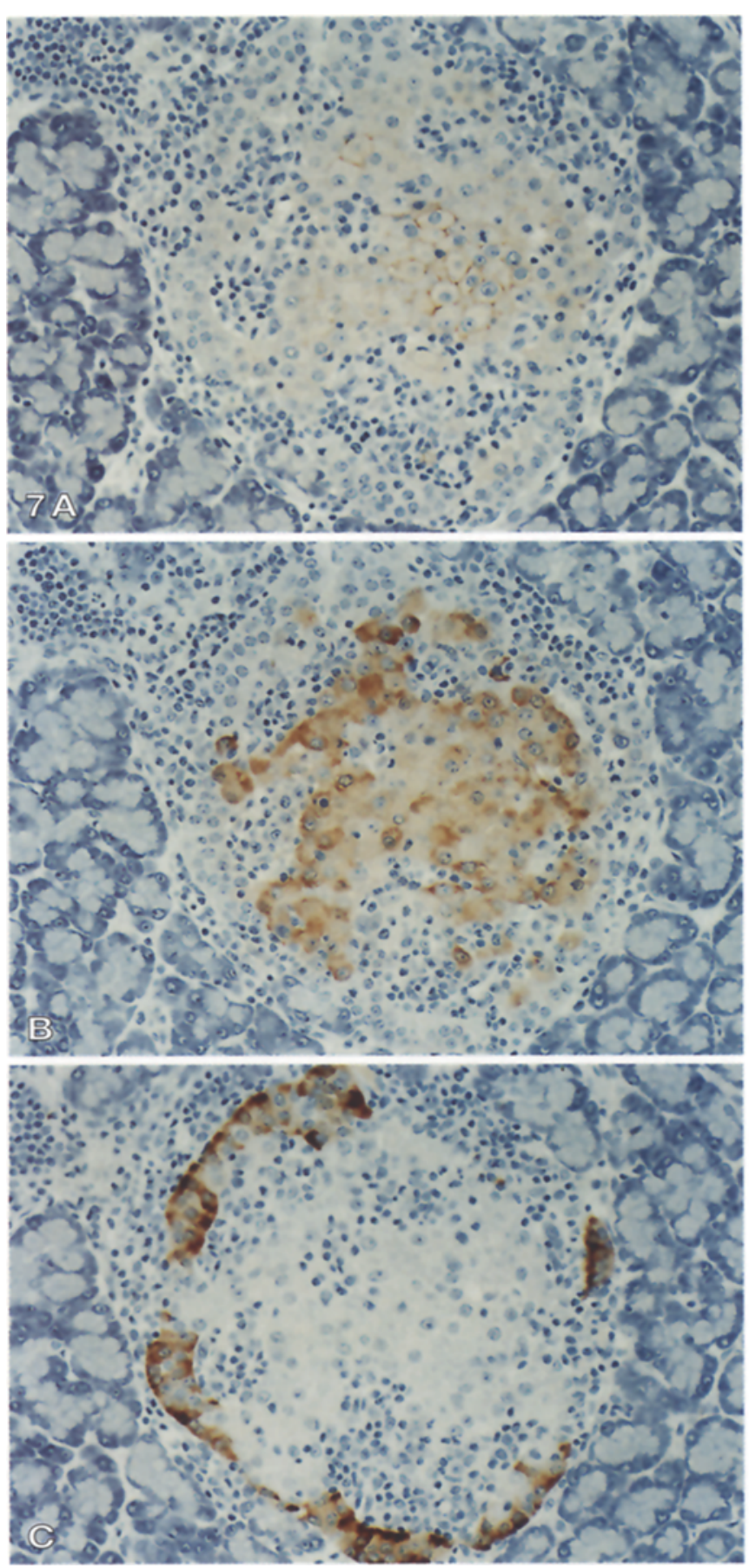

Fig. 7. (A-C). Consecutive or near-consecutive sections of pancreas from KRV-infected diabetes resistant (DR) rats showing severe insulitis. The loss of GLUT 2 is more pronounced where insulitis is more advanced. A reduction in betacell insulin staining (degranulation) can be seen and a disruption in the peripheral pattern of glucagon positive alpha cells. Immunoperoxidase stains for GLUT $2(\mathbf{A})$, insulin $(\mathbf{B})$ and glucagon (C). Magnification $\times 80$

els. Here, we report that in the BBDR/Wor rat model of $\mathrm{KRV}$-induced diabetes, there is no discernable reduction in GLUT 2 staining after KRV inoculation and prior to the onset of lymphocytic insulitis. Only with the presence of advanced lymphocytic insulitis,
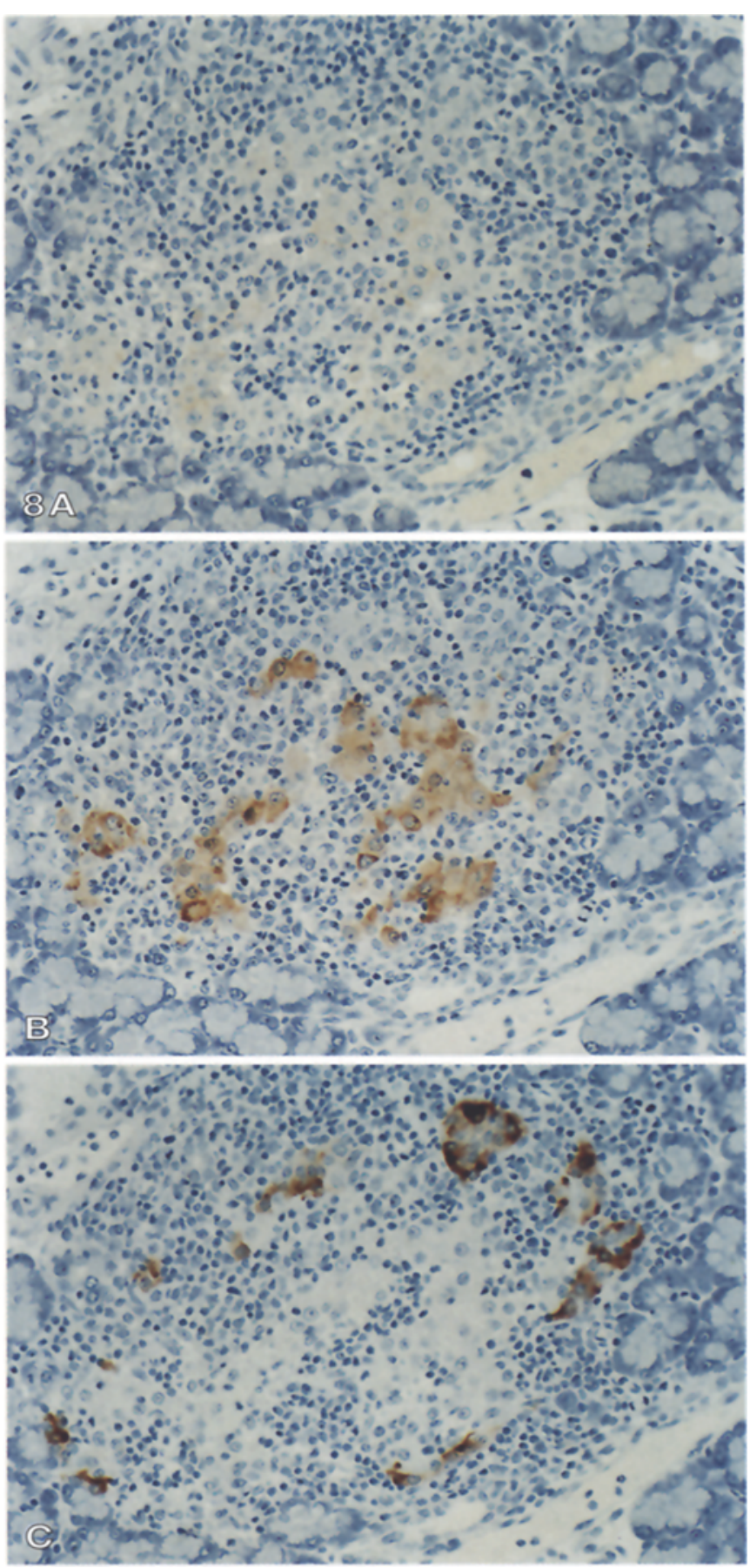

Fig. 8. (A-C). Consecutive or near-consecutive sections of pancreas from KRV-infected diabetes resistant (DR) rats showing severe insulitis. The loss of GLUT 2 is virtually complete and small numbers of beta cells can be seen to survive. A reduction in beta cell insulin staining (degranulation) can be seen and a disruption in the peripheral pattern of glucagon positive alpha cells. Immunoperoxidase stains for GLUT 2 (A), insulin (B) and glucagon (C). Magnification $\times 80$

was there a discernable reduction in beta-cell plasma membrane GLUT 2 staining. Of the nine rats with KRV-induced diabetes, four showed GLUT 2 expression on more than $50 \%$ of surviving beta cells. These observations suggest: (1) that the observed loss of 
GLUT 2 immunostaining is secondary to insulitis rather than a primary event that occurs early in the development of this disease; (2) hyperglycaemia in KRV-infected DR rats is due to beta-cell destruction, rather than the result of the loss of GLUT 2 from otherwise intact beta cells; (3) hyperglycaemia per se is not responsible for loss of betacell GLUT 2; (4) although virus levels in blood and tissues (including the pancreas) are highest at 5 and 7 days post-KRV inoculation [10], the presence of normal GLUT 2 and insulin immunostaining at these early times argues against the possibility that direct infection of beta cells by KRV is responsible for a loss of GLUT 2 mediated glucose transporter function. In addition, the beta cells appear to be morphologically normal and functionally unaffected (animals are normoglycaemic) during the early stages of KRV infection. Histologic evidence of beta-cell loss and reduced GLUT 2 staining was evident only in islets with lymphocytic insulitis. These findings therefore support the hypothesis that the autoimmune process which follows KRV infection of DR rats is the result of a perturbation of the immune system rather than the result of direct virus-induced beta cell injury.

$\mathrm{Tal}$ et al. [18] reported the absence of a correlation between expression of GLUT 2 on beta-cells and glucose uptake and utilization rates. In addition, the rate of glucose transport across the beta-cell membrane was found to be far in excess (about 100-fold) of the rate of glucose utilization. Ohneda et al. [19] reported that glucose-stimulated insulin secretion in 12 week-old diabetic Goto-Kakizaki (GK) rats was reduced by $80 \%$ compared with age-matched control rats, although the number of GLUT 2 positive betacells was reduced by only $10 \%$. A similar discrepancy between the reduction in beta-cell GLUT 2 and loss of glucose-stimulated insulin release has been reported for dexamethasone-induced diabetes in Zucker fatty rats [20]. Chen et al. [21] reported that the restoration of glucose-induced insulin secretion in neonatal streptozotocin diabetic rats induced by perfusion of the pancreas with a glucose-deficient medium occurs without an increase in beta-cell GLUT 2 immunostaining. These results suggest that the loss of GLUT 2 cannot be the sole cause of betacell dysfunction in these models of diabetes. However, if the loss of GLUT 2 is of a sufficient magnitude, then glucose transport may, in fact, become rate-limiting. The enhanced glucose-induced insulin release elicited by glucopenia in neonatal streptozotocin rats was abnormal in that there was a leftward shift of the dose-response curve, with a blunted second phase [21]. Hence, under certain conditions, GLU'T 2 on the plasma membrane of beta cells may in fact contribute to normal glucose responsiveness. Another report [22] suggests that the relationship between GLUT 2 and glucose-induced insulin secretion involves factors other than glucose transport. In- sulin-secreting AtT-20 ${ }_{\text {ins }}$ cells transfected with cDNA for GLUT 2 or GLUT 1 show similar glucose utilization rates. However, only the cells transfected with GLUT 2 cDNA display glucose sensitivity. Therefore, although both transporter isotypes confer similar glucose transport abilities on AtT- $20_{\text {ins }}$ cells, only the GLUT 2 isotype can provide glucose-stimulated insulin release.

As viral proteins and gene products have not been identified in the BBDR/Wor beta cells following KRV infection $[10,23]$, it is unlikely that autoimmune destruction is directly elicited by viral antigens or gene products in or on the beta cell. A proposed mechanism for KRV-induced diabetes in the DR rat is that the virus induces a "disturbance" in the immune system which leads to immune destruction of pancreatic beta cells. That the DR rat possesses a genetic predisposition to develop diabetes is suggested by reports that diabetes can be induced in conventionally housed (i.e. viruses present) DR rats by a variety of experimental procedures that perturb the immune system. Therefore, we predict that the same beta-cell target antigen(s) are the target of the autoimmune attack in both the spontaneous diabetes of the BBDP/ Wor rat and KRV-induced diabetes in the BBDR/ Wor rat. GLUT 2 has been suggested as a putative beta-cell autoantigen $[24,25]$. The results of this study neither support nor contradict this possibility. Since GLUT 2 does not disappear from the beta-cell membrane early in the course of KRV-induced diabetes, the persistence of this protein may conceivably serve as a target for the autoreactive effector cells.

Acknowledgements. The authors wish to thank Ms. S.Costa, Mr. A. Mascarenhas and Ms. M. Gardner for their skillful technical assistance and Ms. L. Urbsis for her much appreciated help in preparing this manuscript. This work was supported by USPHS grant DK-19155 and USPHS Contract NO1-DK2-2201 and product support from Eli Lilly Co., Indianapolis, Indiana, USA.

\section{References}

1. Thorens B, Sarkar HK, Kaback HR, Lodish HF (1988) Cloning and functional expression in bacteria of a novel glucose transporter present in liver, intestine, kidney and B-pancreatic islet cells. Cell 55: 281-290

2. Brant AM, McCoid S, Thomas HM et al. (1992) Analysis of the glucose transporter content of islet cell lines: implications for glucose-stimulated insulin release. Cell Signal 4: $641-650$

3. Johnson JH, Newgard CB, Milburn JL, Lodish HF, Thorens B (1990) The high $K_{\text {m }}$ glucose transporter of islets of Langerhans is functionally similar to the low affinity transporter of liver and has an identical primary sequence. J Biol Chem 265: 6548-6551

4. Johnson JH, Ogawa A, Chen L et al. (1990) Underexpression of $\beta$ cell high $K_{\mathrm{m}}$ glucose transporters in noninsulindependent diabetes. Science 250: 546-549

5. Thorens B, Wu YJ, Leahy JL, Weir GC (1992) The loss of GLUT 2 expression by glucose-unresponsive $\beta$ cells of $\mathrm{db} /$ 
$\mathrm{db}$ mice is reversible and is induced by the diabetic environment. J Clin Invest 90: 77-85

6. Orci L, Ravazzola M, Baetens D et al. (1990) Evidence that down-regulation of $\beta$-cell glucose transporters in non-insulin-dependent diabetes may be the cause of diabetic hyperglycemia. Proc Natl Acad Sci USA 87: 9953-9957

7. Thorens B, Weir GC, Leahy JL, Lodish HF, Bonner-Weir S (1990) Reduced expression of the liver/beta-cell glucose transporter isoform in glucose-insensitive pancreatic betacells of diabetic rats. Proc Natl Acad Sci USA 87: 64926496

8. Orci L, Unger RH, Ravazzola M et al. (1990) Reduced $\beta$-cell glucose transporter in new onset diabetic BB rats. $\mathrm{J}$ Clin Invest $86:$ : 1615-1622

9. Like AA, Guberski DL, Butler L (1991) Influence of environmental viral agents on frequency and tempo of diabetes mellitus in BB/Wor rats. Diabetes 40: 259-262

10. Guberski DL, Thomas VA, Shek WR et al. (1991) Induction of type I diabetes by Kilham's Rat Virus in diabetesresistant BB/Wor rats. Science 254: 1010-1013

11. Thomas VA, Woda BA, Handler ES, Greiner DL, Mordes JP, Rossini AA (1991) Altered expression of diabetes in $\mathrm{BB} /$ Wor rats by exposure to viral pathogens. Diabetes 40 : 255-258

12. Sobel DO, Newsome J, Ewel CH et al. (1991) Poly I : C induces development of diabetes in BB rat. Diabetes 41 : $515-520$

13. Greiner DL, Mordes JP, Handler ES, Angelillo M, Nakamura N, Rossini AA (1987) Depletion of RT6.1 + T lymphocytes induces diabetes in resistant Biobreeding/Worcester (BB/W) rats. J Exp Med 166: 461-475

14. Handler ES, Mordes JP, McKeever U et al. (1989) Effects of irradiation on diabetes in the $\mathrm{BB} /$ Wor rat. Autoimmunity $4: 21-30$

15. Like AA, Weringer EJ, Holdash A, McGill P, Atkinson D, Rossini AA (1985) Adoptive transfer of autoimmune diabetes mellitus in Biobreeding/Worcester (BB/W) inbred and hybrid rats. J Immunol 134: 1583-1587

16. Mojcik CF, Greiner DL, Medlock ES, Komschlies KL, Goldschneider I (1988) Characterisation of RT6 bearing rat lymphocytes. I. Ontogeny of the RT6 + subset Cell Immunol 114: 336-346
17. Greiner DL, Barton RW, Goldschneider I, Lubaroff DM (1982) Genetic linkage and cell distribution analysis of $T$ cell alloantigens in the rat. $J$ Immunogenet 9: 43-50

18. Tal M, Liang Y, Najafi H, Lodish HF, Matschinsky FM (1992) Expression and function of GLUT 1 and GLUT 2 glucose transporter isoforms. J Biol Chem 267: 1724117247

19. Ohneda M, Johnson JH, Inman LR et al. (1993) Glut 2 expression and function in $\beta$-cells of GK rats with NIDDM: dissociation between reductions in glucose transport and glucose-stimulated insulin secretion. Diabetes 42: 10651072

20. Ohneda M, Johnson JH, Inman LR, Unger RH (1993) GLUT 2 function in glucose-unresponsive $\beta$ cells of dexamethasone-induced diabetes in rats. J Clin Invest 92: 1950-1956

21. Chen C, Thorens B, Bonner-Weir S, Weir GC, Leahy JL (1992) Recovery of glucose-induced insulin secretion in a rat model of NIDDM is not accompanied by return of the B-cell GLUT 2 glucose transporter. Diabetes 41: 13201327

22. Hughes SD, Quaade C, Johnson JH, Ferber S, Newgard CB (1993) Transfection of AtT-20 ins cells with GLUT 2 but not GLUT 1 confers glucose-stimulated insulin secretion. J Biol Chem 20: 15205-15212

23. Brown DW, Welsh RM, Like AA (1993) Infection of peripancreatic lymph nodes but not islets precedes Kilham Rat Virus-induced diabetes in BB/Wor rats. J Virol 67: 5873-5878

24. Johnson JH, Crider BP, McCorkle K, Alford M, Unger RH (1990) Inhibition of glucose transport into rat islet cells by immunoglobulins from patients with new-onset insulin-dependent diabetes mellitus. N Engl J Med 322: 653-659

25. Inman LR, McAllister CT, Chen L et al. (1993) Autoantibodies to the GLUT 2 glucose transporter of $\beta$ cells in insulin-dependent diabetes mellitus of recent onset. Proc Natl Acad Sci USA 90: 1281-1284 